\title{
Effects of concentrate crude protein content on nutrient digestibility, energy utilization, and methane emissions in lactating dairy cows fed fresh-cut perennial grass
}

\author{
D. N. Hynes, ${ }^{*} †$ S. Stergiadis, $\ddagger$ A. Gordon, $§$ and T. Yan ${ }^{* 1}$ \\ *Sustainable Agri-Food Sciences Division, Agriculture Branch, Agri-Food and Biosciences Institute, Large Park, Hillsborough, BT26 6DR, \\ United Kingdom \\ †Institute for Global Food Security, School of Biological Sciences, Queen's University Belfast, University Road, Belfast, BT7 1NN, United Kingdom \\ $\ddagger$ Animal, Dairy and Food Chain Sciences Division, Centre for Dairy Research, University of Reading, School of Agriculture, \\ Policy and Development, Earley Gate, PO Box 237, Reading, RG6 6AR, United Kingdom \\ §Finance and Corporate Affairs Division, Biometrics and Information Systems Branch, Agri-Food and Biosciences Institute, 18a Newforge Lane, \\ Belfast, BT9 5PX, United Kingdom
}

\begin{abstract}
Although many studies have investigated mitigation strategies for methane $\left(\mathrm{CH}_{4}\right)$ output from dairy cows fed a wide variety of diets, research on the effects of concentrate crude protein $(\mathrm{CP})$ content on $\mathrm{CH}_{4}$ emissions from dairy cows offered fresh grass is limited. The present study was designed to evaluate the effects of cow genotype and concentrate $\mathrm{CP}$ level on nutrient digestibility, energy utilization, and $\mathrm{CH}_{4}$ emissions in dairy cows offered fresh-grass diets. Twelve multiparous lactating dairy cows $(6$ Holstein and 6 Holstein $\times$ Swedish Red) were blocked into 3 groups for each breed and assigned to a low-, medium-, or high-CP concentrate diet $[14.1,16.1$, and $18.1 \% \mathrm{CP}$ on a dry matter (DM) basis, respectively], in a 3 -period changeover study $(25 \mathrm{~d}$ per period). Total diets contained (DM basis) $32.8 \%$ concentrates and $67.2 \%$ perennial ryegrass, which was harvested daily. All measurements were undertaken during the final $6 \mathrm{~d}$ of each period: digestibility measurements for $6 \mathrm{~d}$ and calorimetric measurements in respiration chambers for $3 \mathrm{~d}$. Feed intake and milk production data were reported in a previous paper. We observed no significant interaction between concentrate CP level and cow genotype on any parameter. Concentrate CP level had no significant effect on any energy utilization parameter, except for urinary energy output, which was positively related to concentrate $\mathrm{CP}$ level. Similarly, concentrate $\mathrm{CP}$ content had no effect on $\mathrm{CH}_{4}$ emission (g/d), $\mathrm{CH}_{4}$ per $\mathrm{kg}$ feed intake, or nutrient digestibility. Cross breeding of Holstein cows significantly reduced gross energy, digestible energy, and metabolizable energy intake, heat production, and milk energy output. However, cow genotype had no significant effect on
\end{abstract}

Received May 25, 2016.

Accepted July 27, 2016.

${ }^{1}$ Corresponding author: tianhai.yan@afbini.gov.uk energy utilization efficiency or $\mathrm{CH}_{4}$ parameters. Furthermore, the present study yielded a value for gross energy lost as $\mathrm{CH}_{4}(5.6 \%)$ on fresh grass-based diets that was lower than the widely accepted value of $6.5 \%$. The present findings indicate that reducing concentrate CP content from 18.1 to $14.1 \%$ may not be a successful way of alleviating $\mathrm{CH}_{4}$ emissions from lactating dairy cows offered good-quality fresh grass, but grazing cows could be offered a low-CP concentrate without compromising energy utilization efficiency. Further research is needed to investigate whether larger differences in dietary $\mathrm{CP}$ content may yield positive results.

Key words: dairy cow, energy utilization, methane, fresh grass

\section{INTRODUCTION}

The agricultural industry is a major contributor of atmospheric methane $\left(\mathrm{CH}_{4}\right)$ and is responsible for $13.5 \%$ of total greenhouse gas emissions globally (IPCC, 2007). A large proportion of these emissions (80\%) come from livestock production systems (FAO, 2006). In Northern Ireland, agriculture is responsible for the emission of $6.49 \mathrm{Mt}$ of $\mathrm{CO}_{2}$ equivalents annually or $29 \%$ of total annual greenhouse gas emissions (Salisbury et al., 2015). Methane emissions not only raise environmental concerns but also form a sizable loss of feed energy intake from dairy and beef cows, from 2 to $12 \%$ (Johnson and Johnson, 1995). Alleviating $\mathrm{CH}_{4}$ emissions may increase the ME available and improve energy utilization efficiency in ruminant systems. Rates of $\mathrm{CH}_{4}$ emission are influenced by a range of diet and animal factors, such as feed intake, diet quality, and nutrient utilization efficiency (Johnson and Johnson, 1995; Kebreab et al., 2006; Muñoz et al., 2015). Many mitigation strategies have been investigated for dairy cows offered ensiled forage, but information for grazing cows is lacking. 
Pasture-based dairy systems are widely used in Ireland and in other countries with similar climatic conditions; $89 \%$ of agricultural land is allocated for grazing swards (Hart et al., 2009). A promising mitigation strategy reported in several studies (Aguerre et al., 2011; Haque et al., 2014) appears to be the increase of dietary starch content, either by increasing concentrate input (which increases feed costs) or by replacing high-protein feed components (e.g., soybean meal, rapeseed extract) with high-starch components (e.g., corn, wheat). However, replacing the $\mathrm{CP}$ content of concentrate with starch in pasture-based diets - a successful strategy for alleviating $\mathrm{N}$ excretion - has not been investigated. In a metaanalysis of indirect calorimetry data from dairy cows offered perennial ryegrass silage-based diets, Yan and Mayne (2007) found a negative relationship between $\mathrm{CH}_{4} /$ kilogram of DMI and dietary CP concentration. This effect was likely not solely dependent on dietary CP concentrations, but a result of changes in other dietary factors (e.g., fiber and starch concentrations). Indeed, Stergiadis et al. (2016) found increasing grass CP and water-soluble carbohydrate concentrations increased $\mathrm{CH}_{4} /$ kilogram of DMI in dry cows offered diets of only fresh perennial ryegrass at maintenance feeding levels. Therefore, the effects of dietary $\mathrm{CP}$ contents on $\mathrm{CH}_{4}$ emissions and energy utilization merit investigation in studies with dairy cows offered fresh-forage diets.

Animal genetic factors have been found to play a significant role in energy utilization efficiency and $\mathrm{CH}_{4}$ emissions from ruminants (Pinares-Patiño et al., 2009; Clark, 2013). It is well documented that improving productivity can lead to a reduction in $\mathrm{CH}_{4}$ emissions per unit of produce (Chagunda et al., 2009; Wall et al., 2010; Cottle et al., 2011) while making mitigation strategies appealing to producers. Beecher et al. (2014) and Palladino et al. (2010) showed that HolsteinFriesian cows on perennial ryegrass silage diets offered at maintenance levels and grazing perennial ryegrass, respectively, may exhibit differences in production efficiency compared with Jersey and Jersey $\times$ HolsteinFriesian cows. However, comparisons of $\mathrm{CH}_{4}$ emissions between Holstein and other breeds under grazing or zero-grazing conditions have been limited, with the literature focusing on ensiled forage (Xue et al., 2011; Arndt et al., 2015).

The present study was designed to address these knowledge gaps by evaluating the effects of reducing concentrate CP content (with little influence on starch and fiber content), cow genotype, and their interaction on nutrient digestibility, energy utilization efficiency, and $\mathrm{CH}_{4}$ emissions in lactating dairy cows offered fresh perennial ryegrass diets, so that practices are widely applicable to pasture-based systems.

\section{MATERIALS AND METHODS}

All scientific procedures described were carried out under experimental license from the Department of Health, Social Services and Public Safety of Northern Ireland in accordance with the Animal (Scientific Procedures) Act (Home Office, 1986).

\section{Experimental Design}

The current study presents observations from a calorimetry experiment performed at Agri-Food and Biosciences Institute (Hillsborough, Northern Ireland, UK), using 12 multiparous lactating (6 Holstein and 6 Holstein $\times$ Swedish Red 50:50 crossbred) cows on diets of fresh-cut perennial ryegrass and concentrate feeds during the 2014 grazing season. Details of the animals, experiment design, and diets are reported in a companion paper (Hynes et al., 2016). A brief description of the design and measurement procedures follows.

Animals were offered 3 dietary treatments with different concentrate $\mathrm{CP}$ contents (2 cows in each genotype/diet) in a changeover study with 3 periods of $25 \mathrm{~d}$. All measurements were taken during the final $6 \mathrm{~d}$ of each period: $3 \mathrm{~d}$ in digestibility units and $3 \mathrm{~d}$ in indirect open-circuit respiration calorimeter chambers, with continuation of digestibility measurements in the respiration chambers. Diets were composed of zero-grazed perennial ryegrass and concentrate feeds of differing CP content: low-CP concentrate (14.1\% DM), medium-CP concentrate (16.1\% DM), and high-CP concentrate $(18.1 \% \mathrm{DM})$ fed at $32.8 \%$ DMI combined with perennial ryegrass fed at $67.2 \%$ DMI. The lowand high-CP concentrates were formulated to possess the same dietary components and similar chemical composition except for $\mathrm{CP}$ level, and the medium-CP concentrate was produced by mixing the low- and high$\mathrm{CP}$ concentrates in equal proportions. This resulted in 3 concentrate feeds that were comparable in terms of $\mathrm{ME}$, fermentable ME, and fiber content. Concentrates were offered at milking $(50 \%$ at $0700 \mathrm{~h}$ and $50 \%$ at 1500 h), and fresh herbage was offered ad libitum at $1000 \mathrm{~h}$ each morning. The zero-grazed herbage was harvested from a single sward each morning using a Haldrup 1500 (Plot Combine, Haldrup, UK) and boxed loosely to avoid nutrient degradation. The temperature of the perennial ryegrass was monitored for the duration of the study. Herbage regrowth intervals (initially $22 \mathrm{~d}$ of regrowth with incremental increases up to $30 \mathrm{~d}$ from June to September) and fertilization practices (within $3 \mathrm{~d}$ of harvesting at $35 \mathrm{~kg}$ of $\mathrm{N} / \mathrm{ha}$ ) were determined based on common routine practices to ensure perennial ryegrass of a similar quality was being offered to animals for 
and quadratic effects of treatment as described by Hynes et al. (2016). Residuals conveyed no deviation from normality. Differences between treatments, genotypes, and interactions were assessed with 5 degrees of significance; nonsignificance was declared at $P>0.10$, significance at $P<0.05, P<0.01$, and $P<0.001$, and tendencies at $0.05<P<0.10$.

\section{RESULTS}

We observed no significant interaction between concentrate $\mathrm{CP}$ level and cow genotype on any parameter evaluated in terms of digestibility, $\mathrm{CH}_{4}$ emissions, energy intake, energy output, or energy utilization efficiency. Therefore, only results of the main factors are presented here. The results for dietary composition, feed intake, and milk production were reported by Hynes et al. (2016); in brief, concentrate CP contents did not affect DMI, milk yield, or milk composition. Concentrate feeds had similar chemical compositions, varying only in $\mathrm{CP}$ content, so that total dietary $\mathrm{CP}$ levels were 16.9, 17.6, and 18.3\% (DM basis) for the low-, medium-, and high-CP concentrate treatments, respectively.

\section{Nutrient Apparent Whole-Tract Digestibility}

Data on nutrient digestibility are presented in Table 2. Findings conveyed no significant effects of dietary treatment or genotype on any apparent whole-tract digestibility parameter (DM, OM, GE, NDF, ADF, or digestible $\mathrm{OM}$ in total $\mathrm{DM})$, but we did observe a tendency for $\mathrm{N}$ digestibility to linearly increase with increasing concentrate $\mathrm{CP}$ content.

\section{Energy Utilization}

Findings on the effects of concentrate CP levels and cow genotype on energy utilization variables are presented in Table 3. Analysis showed no significant effect of dietary treatment on energy intake [GE, digestible energy (DE) or ME], retained energy, or energy partition in feces, $\mathrm{CH}_{4}, \mathrm{HP}$, or milk, but we did observe a positive linear effect of concentrate $\mathrm{CP}$ on urine energy output. We found no significant effect of treatment on $\mathrm{DE} / \mathrm{GE}, \mathrm{ME} / \mathrm{GE}, \mathrm{HP} / \mathrm{MEI}$, or $\mathrm{k}_{1}$.

Compared with the crossbreds, Holstein cows had significantly higher GE, DE, and MEI, and consequently higher HP and milk energy output. Cow genotype had no significant effect on DE/GE, ME/GE, HP/MEI, or $\mathrm{k}_{1}$.

\section{Methane Emissions}

Enteric $\mathrm{CH}_{4}$ emission data are shown in Table 4 . Neither concentrate CP level nor cow genotype had a significant effect on any $\mathrm{CH}_{4}$ emission factor in terms of total emission $(\mathrm{g} / \mathrm{d})$ or $\mathrm{CH}_{4}$ emissions as a proportion of feed intake, milk yield, or $\mathrm{CH}_{4}$ energy $\left(\mathbf{C H}_{4}-\mathbf{E}\right)$ as a proportion of GE intake (GEI). The ratio of $\mathrm{CH}_{4}-\mathrm{E}$ as a proportion of GE, DE, and MEI had mean values of 0.056, 0.076, and $0.089(\mathrm{MJ} / \mathrm{MJ})$, respectively.

\section{DISCUSSION}

Grazing systems are used extensively in areas with cool and moist climates, which allow a long grazing season and high forage production, thus providing a low-cost feeding approach for ruminant production systems (Peyraud and Delagarde, 2013). The profitability of dairying in these areas is fundamentally linked to forage utilization; for example, in Ireland, every extra tonne of forage yield per hectare (DM basis) is worth $€ 161$ (Shalloo, 2009). Although previous work on $\mathrm{CH}_{4}$ emissions in grazing animals relied predominantly on the $\mathrm{SF}_{6}$ tracer method to measure $\mathrm{CH}_{4}$ emissions (Pinares-Patiño et al., 2007; Cavanagh et al., 2008), in the present study we used indirect open-circuit calorimetry chambers. These chambers measured gaseous exchanges, including $\mathrm{CH}_{4}$, and allowed for the calculation

Table 2. Effect of concentrate CP level and cow genotype on total diet digestibility parameters $(\mathrm{kg} / \mathrm{kg})$

\begin{tabular}{|c|c|c|c|c|c|c|c|c|c|c|}
\hline Item & \multicolumn{3}{|c|}{ Concentrate CP level } & SEM & \multicolumn{2}{|c|}{$P$-value ${ }^{1}$} & \multicolumn{2}{|c|}{ Cow genotype } & SEM & $P$-value \\
\hline $\mathrm{DM}$ & 0.759 & 0.764 & 0.762 & 0.0060 & 0.585 & 0.615 & 0.766 & 0.757 & 0.0056 & 0.170 \\
\hline Digestible $\mathrm{OM}$ in $\mathrm{DM}$ & 0.710 & 0.714 & 0.711 & 0.0053 & 0.760 & 0.582 & 0.716 & 0.708 & 0.0049 & 0.185 \\
\hline $\mathrm{N}$ & 0.655 & 0.668 & 0.673 & 0.0118 & 0.088 & 0.667 & 0.667 & 0.664 & 0.0134 & 0.880 \\
\hline Gross energy & 0.740 & 0.745 & 0.741 & 0.0060 & 0.611 & 0.324 & 0.746 & 0.738 & 0.0057 & 0.236 \\
\hline
\end{tabular}

${ }^{1}$ Probability of a linear or quadratic effect of concentrate CP level in the diet.

${ }^{2}$ Crossbred cows were crosses between Holstein and Swedish Red. 

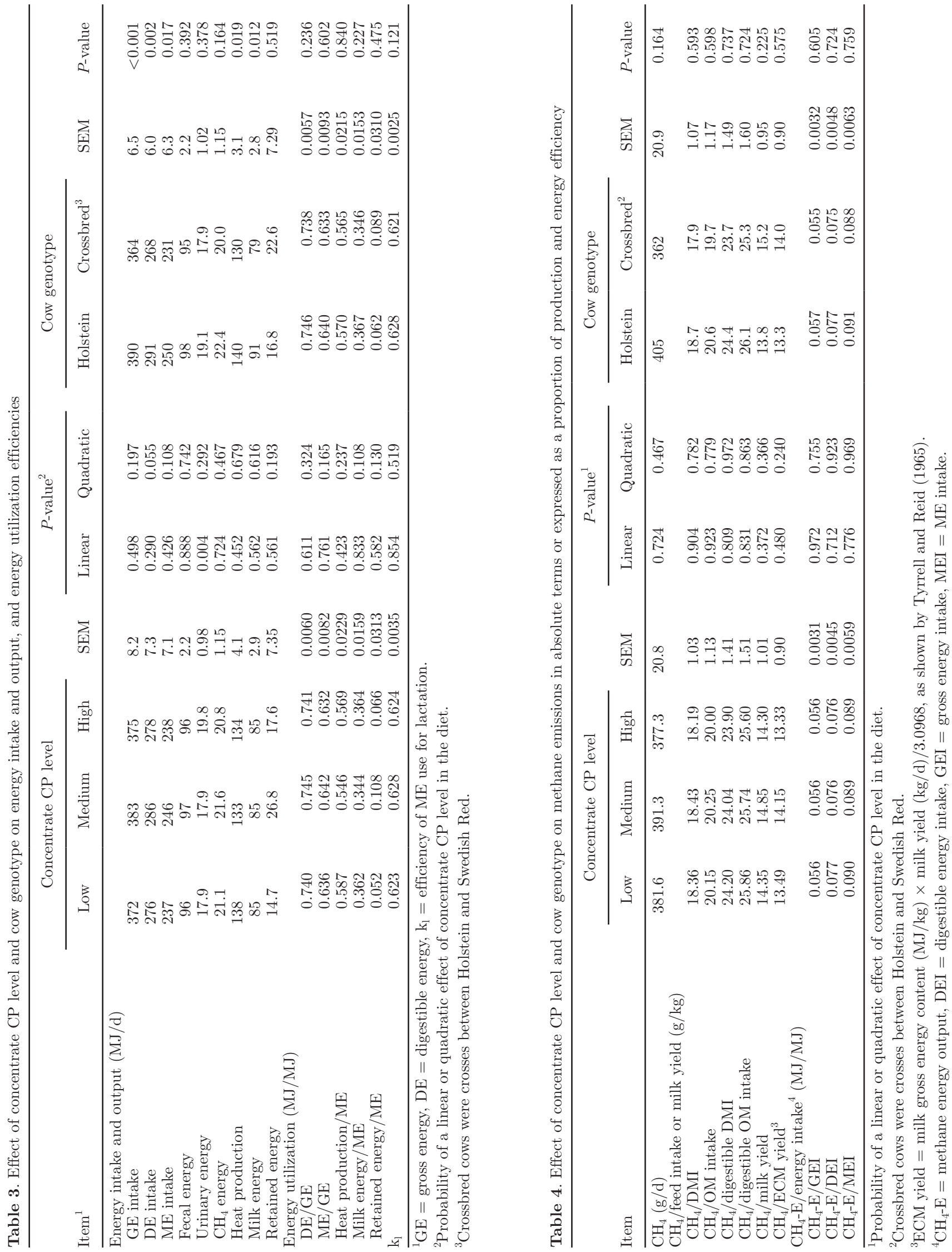
of HP - a variable that could not be measured by the $\mathrm{SF}_{6}$ technique. Although energy expenditure at pasture due to grazing could not be assessed when animals were in the chambers, the results from the present study may be highly applicable to pasture-based systems, due to the zero-grazing practices used, and complement results from studies that use $\mathrm{SF}_{6}$ tracer techniques.

\section{Nutrient Digestibility and Energy Utilization Efficiency}

Due to the relatively high apparent digestibilities in the present study, DMI was high across all treatments; the positive association between highly digestible feed and DMI has been demonstrated previously (NRC, 2001). An apparent DM digestibility of 0.76 in the present study is comparable with published findings $(0.76-0.78)$ for dairy cows on similar diets (Whelan et al., 2012). The lack of effect of dietary treatment on digestibility parameters obtained in the present study was in agreement with results from a study by Moorby et al. (2006) in dairy cows offered diets containing $65 \%$ ryegrass silage and $35 \%$ concentrate. The $\mathrm{N}$ digestibility values in the present study were similar to those observed in studies under a wide variety of dietary regimens (Huhtanen et al., 2008), including fresh-forage diets (Van Vuuren et al., 1992). Increasing N digestibility with increasing dietary $\mathrm{CP}$ concentration, as tended to occur in the present study, reflected the increased urine $\mathrm{N}$ loss with increasing concentrate $\mathrm{CP}$ content, but treatment had no effect on milk $\mathrm{N}$ output or retained $\mathrm{N}$ (Hynes et al., 2016). The NDF (0.725) and OM (0.792) digestibility values obtained in the present study were higher than previously recorded (Nousiainen et al., 2004; Huhtanen et al., 2008), which averaged 0.622 and 0.726 , respectively. This finding may be explained by the good-quality perennial ryegrass offered in the present study, which may have improved feed OM digestibility (Stergiadis et al., 2015).

Energy intakes and outputs (GE, DE, and ME) did not differ across dietary treatments, except for urine energy outputs. The observed differences in urinary energy partitioning were in agreement with previous work (Ramin and Huhtanen, 2013), which reported that urinary energy was positively associated with dietary $\mathrm{CP}$ content with a wide range of dietary treatments $(\mathrm{n}=207)$. This may be due to the associated excess $\mathrm{N}$ in urine that increases urine energy content, as was found to be the case in Holstein steers on concentratebased diets (Mwenya et al., 2004). The lack of effect of diet treatments on energy intake, utilization efficiency, and nutrient digestibility values obtained in the present study may imply that the total dietary $\mathrm{CP}$ content
(16.9\%) of the low-CP concentrate treatment may be sufficient to supply degradable CP for rumen microbial activity and MP for milk production. Indeed, the present study found that increasing concentrate CP levels had no significant effect on total DMI, milk yield or composition, or $\mathrm{N}$ utilization efficiency in terms of $\mathrm{N}$ excretion in feces, urine, or milk as a proportion of $\mathrm{N}$ intake (Hynes et al., 2016). However, increasing concentrate CP levels significantly increased $\mathrm{N}$ excretion in urine and urine $\mathrm{N} /$ manure $\mathrm{N}$. It is a common practice in dairy farming in Northern Ireland to feed dairy cows grazing diets and winter diets containing CP content of approximately 18\% (DM basis). However, the present study clearly demonstrated that a grazing diet at a $\mathrm{CP}$ content of $17 \%$ (DM basis) was enough to sustain milk production as reported by Hynes et al. (2016), as well as energy digestibility, metabolizability, and $\mathrm{k}_{1}$. Further investigation into the long-term effects on production efficiency and other functional traits (e.g., fertility) need to be evaluated. Feeding dairy cows low-CP diets may save on costs of high-priced protein feeds (e.g., soybean meal), and reduce the environmental footprint (urinary $\mathrm{N}$ excretion).

The present study demonstrated that cross-breeding Holstein cows with Swedish Red sires had no effects on nutrient and energy digestibility, energy metabolizability, or $\mathrm{k}_{1}$ when cows were offered diets of fresh perennial ryegrass, although Holstein cows had significantly greater GE, DE, and MEI. Several previous studies had similar results with ensiled forage. Xue et al. (2011) observed no difference in energy metabolizability or $\mathrm{k}_{\mathrm{l}}$ between Holstein and Jersey-Holstein cows offered perennial ryegrass silage diets containing either 30 or $70 \%$ concentrates. Heins et al. (2008) also reported that the feed efficiency for d 4 to 150 of lactation was similar for Jersey-Holstein and pure Holstein cows offered diets containing alfalfa hay and corn silage. These results, along with those from the present study, indicate that cross breeding Holstein cows with Swedish Red or Jersey sires has negligible influence on the potential high-production efficiency of the Holstein breed. Swedish Red cows have traditionally been selected for milk production and other functional traits (e.g., fertility, disease resistance) and have a longer service term than Holstein cows (Swalve, 2007). Consequently, Swedish Red sires have been widely used to improve the reproductive performance and health status of Holstein cows. The present study indicates that although the crossbred cows had a lower feed intake and milk yield, as reported by Hynes et al. (2016), energy digestibility, energy metabolizability, and $\mathrm{k}_{1}$ traits were not compromised compared with pure Holstein cows offered diets of fresh perennial ryegrass. 


\section{Methane Emissions}

The present finding - that dietary $\mathrm{CP}$ concentration did not affect $\mathrm{CH}_{4}$ emissions - is in agreement with Van Dorland et al. (2007). However, in a meta-analysis of calorimetry data, Yan and Mayne (2007) found a negative relationship between $\mathrm{CH}_{4} / \mathrm{kg}$ of DMI and dietary CP concentration. Conversely, Stergiadis et al. (2016) found that increasing perennial ryegrass CP and water-soluble carbohydrate contents also increased $\mathrm{CH}_{4} / \mathrm{kg}$ of DMI in dry cows offered fresh perennial ryegrass-only diets at maintenance level. Arndt et al. (2015) suggested a quadratic relationship between $\mathrm{CH}_{4}$ (g/d, g/kg of DMI, and MJ/MJ of GEI) and dietary $\mathrm{CP}$ with different ratios of alfalfa silage to corn silage. It is difficult to determine the root cause of changes in $\mathrm{CH}_{4}$ yields, but Hassanat et al. (2013) suggested it might be due to increasing dietary starch content and decreasing $\mathrm{CP}$ content, resulting in a decrease in $\mathrm{pH}$, protozoa, and methanogens. Similarly, Dijkstra et al. (2011) speculated that yields of $\mathrm{CH}_{4}$ might decrease when starch increases at the expense of $\mathrm{CP}$ content, due to fermentation of fiber, producing higher volumes of VFA, acetate, and butyrate. These yield $\mathrm{H}_{2}$, a precursor of methanogenesis, in comparison to starch, which results in higher volumes of propionate, a reaction that uses $\mathrm{H}_{2}$. This hypothesis implies that altered fiber or starch concentration can affect enteric $\mathrm{CH}_{4}$ outputs in addition to reduced urinary $\mathrm{N}$ output when dietary $\mathrm{N}$ content decreases (Külling et al., 2001; Weiss et al., 2009; Arndt et al., 2015), but the outcome of the present study did not confirm this. In the present study, the formulation of concentrate supplements did not alter NDF and ADF concentrations. Although increasing $\mathrm{CP}$ content led to decreased starch content in the 3 concentrates, the differences in starch content were relatively small (21.1 to $23.2 \%$ on a DM basis) between the 3 concentrates and negligible (6.9 to $7.6 \%$ ) between total diets. The present study suggests that increasing concentrate $\mathrm{CP}$ content, resulting in a concomitant increase in total dietary CP content from 16.9 to $18.3 \%$, had no effects on enteric $\mathrm{CH}_{4}$ emission rates for perennial ryegrass and concentrate-based diets.

The present study found that cross breeding of Holstein cows with Swedish Red sires had no significant effect on $\mathrm{CH}_{4} / \mathrm{kg}$ of DMI, $\mathrm{CH}_{4} / \mathrm{kg}$ of $\mathrm{OM}$ intake, or $\mathrm{CH}_{4}$-E/GEI (MJ/MJ); $\mathrm{CH}_{4} / \mathrm{kg}$ of ECM yield was identical between the 2 genotypes. Although no comparable calorimetry data with fresh ryegrass were available, Yan and Mayne (2009) observed a similar result when comparing Holstein and Jersey $\times$ Holstein cows offered diets containing perennial ryegrass silage and either $30 \%$ or $70 \%$ concentrate. Several recent studies have assessed the potential association between enteric $\mathrm{CH}_{4}$ emissions and the microbial ecology of ruminal methanogens. Using culture-independent methods, Zhou et al. $(2009,2010)$ reported that although they observed no significant difference in the total population of methanogens between cattle with different feed efficiencies, their rumen methanogenesis capacity was highly related to changes in feed intake and dietary composition. The abundance of predominant methanogenic species obtained on the low-energy-density diet shifted to a community containing a more diverse range of predominant species with the high-energy-density diet (Zhou et al., 2010). These results indicated that enteric $\mathrm{CH}_{4}$ emission rates in cattle are driven mainly by feed intake and dietary nutrient composition, and that cow genotypes based on the Holstein breed may have little effect on inherent genetic capacity for rumen methanogenesis. Heritability for $\mathrm{CH}_{4}$ emissions in Holstein cows is low (Lassen and Løvendahl, 2016). Hence, rather than breeding for reduced $\mathrm{CH}_{4}(\mathrm{~g} / \mathrm{d})$ or $\mathrm{CH}_{4} / \mathrm{kg}$ of DMI, Cottle et al. (2011) have suggested that a breeding approach for improved feeding efficiency would be more successful and in line with current breeding objectives, so as to minimize the risk of undesirable trade-offs.

In the present study, GEI lost as $\mathrm{CH}_{4}$-E averaged $5.6 \%$. This figure was very close to the simulated prediction (5.8\%) by Bannink et al. (2010) with lactating dairy cows on a similar DMI and fresh forage-to-concentrate ratio, and similar to that (average 5.7\%) of grazing dairy cows with $\mathrm{CH}_{4}$ emissions measured using the $\mathrm{SF}_{6}$ technique (O'Neill et al., 2012; Jiao et al., 2014). However, these $\mathrm{CH}_{4} / \mathrm{GEI}$ data were all lower than that of $6.5 \%$ recommended by the IPCC (2006) to calculate enteric $\mathrm{CH}_{4}$ emission inventory for a region where local $\mathrm{CH}_{4}$ emission data are not available. Therefore, it is possible that using the Intergovernmental Panel on Climate Change default value for inventory purposes would overestimate $\mathrm{CH}_{4}$ production in grazing systems, especially for countries where grazing management regimens are a major component of dairy production, such as in Ireland, the United Kingdom, New Zealand, and Australia. This issue merits further investigation.

\section{CONCLUSIONS}

The results from the current study suggest that reducing concentrate CP content from 18.1 to $14.1 \%$ did not affect energy utilization efficiency or enteric $\mathrm{CH}_{4}$ emission rates in lactating dairy cows on diets of freshcut perennial ryegrass. Cross breeding Holstein cows with Swedish Red sires had no significant effect on energy utilization efficiency or enteric $\mathrm{CH}_{4}$ emission rates, although Holstein cows had higher energy intake and milk energy output. These findings suggest that concentrates with CP levels as low as $14.1 \%$ can be offered 
in combination with good-quality perennial ryegrass without any negative effect on $\mathrm{CH}_{4}$ emissions or energy partitioning for production, although production sustainability would have to be confirmed in a long-term study. Feeding grazing cows with low-CP concentrates not only reduces feed costs but is also environmentally beneficial, with lower urinary $\mathrm{N}$ excretion.

\section{ACKNOWLEDGMENTS}

This study was funded by the Department of Agriculture, Food and the Marine of the Republic of Ireland as part of a stimulus-funded project (1S105). The authors acknowledge technical assistance from the staff of the Agri-Food and Bioscience Institute Hillsborough Ruminant Nutrition Unit and Laboratory.

\section{REFERENCES}

AFRC. 1993. Energy and Protein Requirements of Ruminants. Agricultural and Food Research Council. CAB Int., Wallingford, Oxon, UK.

Agnew, R. E., T. Yan, J. France, E. Kebreab, and C. Thomas. 2004. Energy requirement and supply. Pages $11-20$ in Feed into Milk: A New Applied Feeding System for Dairy Cows. C. Thomas, ed. Nottingham Univ. Press, Nottingham, UK.

Aguerre, M. J., M. A. Wattiaux, J. M. Powell, G. A. Broderick, and C. Arndt. 2011. Effect of forage-to-concentrate ratio in dairy cow diets on emission of methane, carbon dioxide, and ammonia, lactation performance, and manure excretion. J. Dairy Sci. 94:3081-3093.

Arndt, C., J. M. Powell, M. J. Aguerre, and M. A. Wattiaux. 2015. Performance, digestion, nitrogen balance, and emission of manure ammonia, enteric methane, and carbon dioxide in lactating cows fed diets with varying alfalfa silage-to-corn silage ratios. J. Dairy Sci. 98:418-430.

Bannink, A., M. C. J. Smits, E. Kebreab, J. A. N. Mills, J. L. Ellis, A. Klop, J. France, and J. Dijkstra. 2010. Simulating the effects of grassland management and grass ensiling on methane emission from lactating cows. J. Agric. Sci. 148:55-72.

Beecher, M., F. Buckley, S. M. Waters, T. M. Boland, D. EnriquezHidalgo, M. H. Deighton, M. O'Donovan, and E. Lewis. 2014. Gastrointestinal tract size, total-tract digestibility, and rumen microflora in different dairy cow genotypes. J. Dairy Sci. 97:3906-3917.

Brouwer, E. 1965. Report of the sub-committee on constants and factors. Pages 441-443 in Energy Metabolism of Farm Animals. K. L. Blaxter, ed. European Association of Animal Production Publication No. 11. Academic Press, London, UK.

Cavanagh, A., L. McNaughton, H. Clark, C. Greaves, J. M. Gowan, C. Pinares-Patiño, D. Dalley, B. Vlaming, and G. Molano. 2008. Methane emissions from grazing Jersey $\times$ Friesian dairy cows in mid lactation. Aust. J. Exp. Agric. 48:230-233.

Chagunda, M. G. G., D. A. M. Roemer, and D. J. Roberts. 2009. Effect of genotype and feeding regime on enteric methane, non-milk nitrogen and performance of dairy cows during the winter feeding period. Livest. Sci. 122:323-332.

Clark, H. 2013. Nutritional and host effects on methanogenesis in the grazing ruminant. Animal 7:41-48.

Cottle, D. J., J. V. Nolan, and S. G. Wiedemann. 2011. Ruminant enteric methane mitigation: A review. Anim. Prod. Sci. 51:491-514.

Dijkstra, J., O. Oenema, and A. Bannink. 2011. Dietary strategies to reducing $\mathrm{N}$ excretion from cattle: Implications for methane emissions. Curr. Opin. Environ. Sustain. 3:414-422.

FAO (Food and Agriculture Organization of the United Nations). 2006. Livestock's role in climate change and air pollution. Livestock's long shadow. Environmental issues and options. Accessed Apr. 3, 2016. ftp://ftp.fao.org/docrep/fao/010/a0701e/a0701e.pdf.

Gilmour, A. R., R. Thompson, and B. R. Cullis. 1995. Average information REML: An efficient algorithm for variance parameter estimation in linear mixed models. Biometrics 51:1440-1450.

Gordon, F. J., M. G. Porter, C. S. Mayne, E. F. Unsworth, and D. J. Kilpatrick. 1995. Effect of forage digestibility and type of concentrate on nutrient utilization for lactating dairy cattle. J. Dairy Res. 62:15-27.

Haque, M. N., C. Cornou, and J. Madsen. 2014. Estimation of methane emission using the $\mathrm{C} 02$ method from dairy cows fed concentrate with different carbohydrate compositions in automatic milking system. Livest. Sci. 164:57-66.

Hart, K. J., P. G. Martin, P. A. Foley, D. A. Kenny, and T. M. Boland. 2009. Effect of sward dry matter digestibility on methane production, ruminal fermentation, and microbial populations of zero-grazed beef cattle. J. Anim. Sci. 87:3342-3350.

Hassanat, F., R. Gervais, C. Julien, D. I. Massé, A. Lettat, P. Y. Chouinard, H. V. Petit, and C. Benchaar. 2013. Replacing alfalfa silage with corn silage in dairy cow diets: Effects on enteric methane production, ruminal fermentation, digestion, $\mathrm{N}$ balance, and milk production. J. Dairy Sci. 96:4553-4567.

Heins, B. J., L. B. Hansen, A. J. Seykora, A. R. Hazel, D. G. Johnson, and J. G. Linn. 2008. Crossbreds of Jersey $\times$ Holstein compared with pure Holsteins for body weight, body condition score, dry matter intake, and feed efficiency during the first one hundred fifty days of first lactation. J. Dairy Sci. 91:3716-3722.

Home Office. 1986. Guidance on the Operation of the Animals (Scientific Procedures) Act 1986. Her Majesty's Stationery Off., London, UK.

Huhtanen, P., J. I. Nousiainen, M. Rinne, K. Kytölä, and H. Khalili. 2008. Utilization and partition of dietary nitrogen in dairy cows fed grass silage-based diets. J. Dairy Sci. 91:3589-3599.

Hynes, D. N., S. Stergiadis, A. Gordon, and T. Yan. 2016. Effects of crude protein levels in concentrate supplements on animal performance and nitrogen utilization of lactating dairy cows fed freshcut perennial grass. J. Dairy Sci. 99:8111-8121. 10.3168/jds.201611110.

VSN International. 2013. GenStat for Windows. 16th ed. VSN International, Hemel Hempstead, UK.

IPCC (Intergovernmental Panel on Climate Change). 2006. 2006 IPCC Guidelines for National Greenhouse Gas Inventories, Vol. 4: Agriculture, Forestry and Other Land Use, Intergovernmental Panel on Climate Change. Accessed Apr. 3, 2016. http://www. ipcc-nggip.iges.or.jp/public/2006gl/pdf/ 4_Volume4/V4_10_ Ch10_Livestock.pdf.

IPCC (Intergovernmental Panel on Climate Change). 2007. Climate Change 2007: IPCC Fourth Assessment Report. Cambridge University Press, Cambridge, UK.

Jiao, H. P., T. Yan, D. A. McDowell, A. F. Carson, C. P. Ferris, D. L. Easson, and D. Wills. 2013. Enteric methane emissions and efficiency of use of energy in Holstein heifers and steers at age of six months. J. Anim. Sci. 91:356-362.

Jiao, H. P., A. J. Dale, A. F. Carson, S. Murray, A. W. Gordon, and C. P. Ferris. 2014. Effect of concentrate feed level on methane emissions from grazing dairy cows. J. Dairy Sci. 97:7043-7053.

Johnson, K. A., and D. E. Johnson. 1995. Methane emissions from cattle. J. Anim. Sci. 73:2483-2492.

Kebreab, E., K. Clark, C. Wagner-Riddle, and J. France. 2006. Methane and nitrous oxide emissions from Canadian animal agriculture: A review. Can. J. Anim. Sci. 86:135-158.

Külling, D. R., H. Menzi, T. F. Kröber, A. Neftel, F. Sutter, P. Lischer, and M. Kreuzer. 2001. Emissions of ammonia, nitrous oxide and methane from different types of dairy manure during storage as affected by dietary protein content. J. Agric. Sci. 137:235-250.

Lassen, J., and P. Løvendahl. 2016. Heritability estimates for enteric methane emissions from Holstein cattle measured using noninvasive methods. J. Dairy Sci. 99:1959-1967.

Moorby, J. M., R. J. Dewhurst, R. T. Evans, and J. L. Danelón. 2006. Effects of dairy cow diet forage proportion on duodenal nutri- 
ent supply and urinary purine derivative excretion. J. Dairy Sci. 89:3552-3562.

Muñoz, C., S. Hube, J. M. Morales, T. Yan, and E. M. Ungerfeld. 2015. Effects of concentrate supplementation on enteric methane emissions and milk production of grazing dairy cows. Livest. Sci. $175: 37-46$.

Mwenya, B., X. Zhou, B. Santoso, C. Sar, Y. Gamo, T. Kobayashi, and J. Takahashi. 2004. Effects of probiotic-vitacogen and beta 1-4 galacto-oligosaccharides supplementation on methanogenesis and energy and nitrogen utilization in dairy cows. Asian-australas. J. Anim. Sci. 17:349-354.

Nousiainen, J., K. J. Shingfield, and P. Huhtanen. 2004. Evaluation of milk urea nitrogen as a diagnostic of protein feeding. J. Dairy Sci. 87:386-398.

NRC (National Research Council). 2001. Nutrient Requirements of Dairy Cattle. 7th rev. ed. Natl. Acad. Press, Washington, DC.

O'Neill, B. F., M. H. Deighton, B. M. O'Loughlin, N. Galvin, M. O'Donovan, and E. Lewis. 2012. The effects of supplementing grazing dairy cows with partial mixed ration on enteric methane emissions and milk production during mid to late lactation. J. Dairy Sci. 95:6582-6590.

Palladino, R. A., F. Buckley, R. Prendiville, J. J. Murphy, J. Callan, and D. A. Kenny. 2010. A comparison between Holstein-Friesian and Jersey dairy cows and their $\mathrm{F}_{1}$ hybrid on milk fatty acid composition under grazing conditions. J. Dairy Sci. 93:2176-2184.

Peyraud, J. L., and R. Delagarde. 2013. Managing variations in dairy cow nutrient supply under grazing. Animal 7:57-67.

Pinares-Patiño, C. S., P. D'Hour, J. P. Jouany, and C. Martin. 2007. Effects of stocking rate on methane and carbon dioxide emissions from grazing cattle. Agric. Ecosyst. Environ. 121:30-46.

Pinares-Patiño, C. S., G. C. Waghorn, R. S. Hegarty, and S. O. Hoskin. 2009. Effects of intensification of pastoral farming on greenhouse gas emissions in New Zealand. N. Z. Vet. J. 57:252-261.

Ramin, M., and P. Huhtanen. 2013. Development of equations for predicting methane emissions from ruminants. J. Dairy Sci. 96:24762493.

Salisbury, E. T. G., K. Young, L. Cardenas, and A. Thomson. 2015. Report: Greenhouse Gas Inventories for England, Scotland, Wales and Northern Ireland: 1990-2013. Accessed Apr. 3, 2016. http:// naei.defra.gov.uk/reports/reports?report_id $=810$

Shalloo, L. 2009. Pushing the barriers of milk production costs/ outputs. Pages 19-38 in Proc. Natl. Dairy Conf., Mullingar and Killarney, Ireland. Teagasc, Oak Park, Carlow, Ireland.

Stergiadis, S., M. Allen, X. J. Chen, D. Wills, and T. Yan. 2015. Prediction of nutrient digestibility and energy concentrations in fresh grass using nutrient composition. J. Dairy Sci. 98:3257-3273.

Stergiadis, S., C. X. Zou, X. J. Chen, M. Allen, D. Wills, and T. Yan. 2016. Equations to predict methane emissions from cows fed at maintenance energy level in pasture-based systems. Agric. Ecosyst. Environ. 220:8-20.
Swalve, H. H. 2007. Crossbreeding in dairy cattle: International trends and results from crossbreeding data in Germany. Lohmann Inf. 42:38-46.

Tyrrell, H. F., and J. T. Reid. 1965. Prediction of the energy value of cow's milk. J. Dairy Sci. 48:1215-1223.

Van Dorland, H. A., H. R. Wettstein, H. Leuenberger, and M. Kreuzer. 2007. Effect of supplementation of fresh and ensiled clovers to ryegrass on nitrogen loss and methane emission of dairy cows. Livest. Sci. 111:57-69.

Van Vuuren, A. M., F. Krolkramer, R. A. Vanderlee, and H. Corbijn. 1992. Protein digestion and intestinal amino acids in dairy-cows fed fresh Lolium perenne with different nitrogen contents. J. Dairy Sci. 75:2215-2225.

Wall, E., G. Simm, and D. Moran. 2010. Developing breeding schemes to assist mitigation of greenhouse gas emissions. Animal 4:366-376.

Weiss, W. P., L. B. Willett, N. R. St-Pierre, D. C. Borger, T. R. McKelvey, and D. J. Wyatt. 2009. Varying forage type, metabolizable protein concentration, and carbohydrate source affects manure excretion, manure ammonia, and nitrogen metabolism of dairy cows. J. Dairy Sci. 92:5607-5619.

Whelan, S. J., K. M. Pierce, C. McCarney, B. Flynn, and F. J. Munigan. 2012. Effect of supplementary concentrate type on nitrogen partitioning in early lactation dairy cows offered perennial ryegrass-based pasture. J. Dairy Sci. 95:4468-4477.

Xue, B., T. Yan, C. F. Ferris, and C. S. Mayne. 2011. Milk production and energy efficiency of Holstein and Jersey-Holstein crossbred dairy cows offered diets containing grass silage. J. Dairy Sci. 94:1455-1464.

Yan, T., R. E. Agnew, F. J. Gordon, and M. G. Porter. 2000. Prediction of methane energy output in dairy and beef cattle offered grass silage-based diets. Livest. Prod. Sci. 64:253-263.

Yan, T., and C. S. Mayne. 2007. Mitigation strategies to reduce methane emission from dairy cows. Pages $345-348$ in Proc. Br. Soc. Anim. Sci., High Value Grassland: Providing Biodiversity, a Clean Environment and Premium Products. University of Keele, Staffordshire, UK.

Yan, T., and C. S. Mayne. 2009. Effect of level of concentrate supplementation on methane emission of Holstein and Holstein-Jersey dairy cows. Page 26 in Proc. Br. Soc. Anim. Sci. Br. Soc. Anim. Sci., Southend, UK.

Zhou, M., E. Hernandez-Sanabria, and L. L. Guan. 2009. Assessment of the microbial ecology of ruminal methanogens in cattle with different feed efficiencies. Appl. Environ. Microbiol. 75:6524-6533.

Zhou, M., E. Hernandez-Sanabria, and L. L. Guan. 2010. Characterization of variation in rumen methanogenic communities under different dietary and host feed efficiency conditions, as determined by PCR-denaturing gradient gel electrophoresis analysis. Appl Environ. Microbiol. 76:3776-3786. 